\author{
RÁCZ, ATTILA PHD
}

atiracz@socio.u-szeged.hu

lecturer (University of Szeged, Department of Sociology)

\title{
The effects of World War I on marriages between 1914 and 1918 in Hungary
}

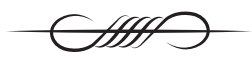

\begin{abstract}
The 20th century has entered the history of Europe as a constant era of wars, crises and dictatorships. This century also marked a series of trials for Hungary. The imprint and long-term effects of the historical events of the period can be well traced with the help of statistical data, therefore the aim of our study is to show how serious and difficult to remedy social, economic and demographic problems can be when people attack people, either with weapons or by another method. In the present study, we analyze the effects of World War I on marriages between 1914 and 1918.
\end{abstract}

\section{KEYWORDS}

war, marriages, demography

DOI 10.14232/belv.2020.3.9

https://doi.org/10.14232/belv.2020.3.9

Cikkre való hivatkozás / How to cite this article:

Rácz, Attila (2020): The effects of World War I on marriages between 1914 and 1918 in Hungary. Belvedere Meridionale vol. 32. no. 3. 115-122. pp

ISSN 1419-0222 (print)

ISSN 2064-5929 (online, pdf)

(Creative Commons) Nevezd meg! - Így add tovább! 4.0 (CC BY-SA 4.0) 
(Creative Commons) Attribution-ShareAlike 4.0 International (CC BY-SA 4.0)

www.belvedere-meridionale.hu

\section{THE NATURE OF WARS IN THE LIGHT OF STATISTICS}

When it comes to statistics of war loss lists, the focus is on soldiers who have fallen, disappeared, possibly captured or wounded during combat operations, as well as civilian casualties in areas affected by various military operations. The indirect effects of wartime periods, which appear only later, after the events of war, in population, its composition, state of health, and other characteristics, often receive less attention. Knowledge of the statistics of military casualties is essential for both the military leadership and the political power to emerge victorious from an armed conflict.

In historical Hungary (excluding Croatian-Slavonian countries), before the outbreak of World War I, the number of marriages per thousand inhabitants was so high that it occupied a prominent place in the ranking of European states. However, during the war, the number of covenants dropped significantly.

The effect of the war on marriage can be seen as early as the first five months of the war of 1914. The decline was greatest in 1915, after which, by 1918, marriage was slowly recurring.

A volume of studies (BODART) published in 1916 uses statistical data to show how the wars and armed conflicts between Austria and Hungary between 1618 and 1913 developed, what changes can be observed in terms of the length of wars and the characteristics of acts of war. The statistics published by the study show that during the 300 years analyzed, the number of wars waged by Austria-Hungary increased, the number of years spent in wars decreased, and the average duration of wars decreased from 6 to 1 year. The increase in the number of wars and the decrease in the average duration together claimed more casualties. After the Napoleonic Wars, armed conflicts became more and more violent. (BODART 1916)

The length of periods of war has the same effect on the losses suffered during military operations as it does on demographic processes that can be perceived later. In war-torn countries, the number of births is greatly reduced due to the retreat of men to war and the protracted nature of hostilities.

In some of the countries involved in World War I, the birth rate fell to half normal, which means that the actual loss of life in the dead in the Great War was not as much as the loss due to missed births.

\section{POSTPONED MARRIAgeS}

In historical Hungary (excluding Croatian-Slavonian countries), before the outbreak of World War I, the number of marriages per thousand inhabitants was so high that it occupied a prominent place in the ranking of European states. However, during the war, the number of covenants dropped significantly. 
The effect of the war on marriage can be seen as early as the first five months of the war of 1914. The decline was greatest in 1915, after which, by 1918, marriage was slowly recurring. The number of marriages fluctuated between 1870 and 1913. The number of marriages per thousand inhabitants - in the period under study - was the highest in 1873, which could not be surpassed in the following years.(KSH 2008) While the difference in the number of marriages observed during the peacetime can be attributed mainly to economic and social phenomena such as changes in agricultural yields, it can no longer be directly related to these factors during the war. (KSH 1924)

In 1913, the number of covenants even exceeded 170,000, which is even higher than usual in peacetime. This was followed by a major setback, which had its effects as early as the five war months of 1914. Nothing indicates war losses better than the fact that from August 1, 1914, to October 31,1918 , only 47 percent of the average of the previous peaceful years was tied up.

TABLE 1.

Marriages

\begin{tabular}{|c|c|c|c|}
\hline Year & Number of marriages & $\begin{array}{c}\text { Increase (+) decrease (-) compared } \\
\text { to the previous year }\end{array}$ & $\begin{array}{c}\text { Per thousand } \\
\text { inhabitants }\end{array}$ \\
\hline 1913 & 172050 & +10945 & 9.2 \\
\hline 1914 & 136337 & -35713 & 7,2 \\
\hline 1915 & 60948 & -75389 & 3,2 \\
\hline 1916 & 62866 & +1918 & 3,4 \\
\hline 1917 & 75745 & +12879 & 4,1 \\
\hline $1918^{\text {a) }}$ & 126894 & +51149 & 6,9 \\
\hline
\end{tabular}

a) Data from October 1918 are incomplete.

Source: A Magyar Szent Korona Országainak 1913-1918. évi népmozgalma. 3.

The number of marriages was the lowest between 1915 and 1916, when half as many covenants were born compared to the average of the pre-World War years. A decree, which came into force on December 1, 1916, to increase the desire to marry, allowed prisoners of war, hostages, and wounded away from their homes to marry their chosen ones by proxy.

Although a year later, in 1917, 20 percent more people chose the institution of marriage than the year before, the real breakthrough came in 1918, when men returned home from the front. (HeInz 2000) Of the approximately 140,000 marriages postponed between 1914 and 1918, 90,000 were eventually concluded later. After a few years, the remarriage of the widows resulted in a marriage surplus. (CSERNÁK 1996)

In addition to the decline in the desire to marry, the men enlisted as soldiers, blood loss and the unfavorable economic situation, among other things, also contributed to the drastic decrease in the number of marriages.

Act XXXI of 1894, in force from 1895 to 1953 , in addition to introducing the institution of compulsory civil marriage, the law also contained a number of regulations and obstacles 
to marriage, which presumably no longer had a significant effect on the number of marriages during the war. Until the announcement of the public decree signed on January 20, 1913, the recruits could not marry before the age of 24 , which delayed the formation of the family. Members of the armed bodies were subject to stricter rules. The right to marry, subject to a royal license and covering only a certain percentage of the regiment's officers, and the deposit of a marriage deposit all made it hard the prospects of officers wishing to marry.

"The Austro-Hungarian officers - including the officers of the Hungarian Royal Army and the Austrian Landwehr - could only marry with strict obligations and permission. Failure to obtain a permit threatened to lead to job losses. Crewed non-commissioned officers were also allowed to marry only with permission, and conscripts were prohibited from marrying before reaching the conscription age. The roots of the regulation go back to the reign of Maria Theresa. An ordinance issued in 1750 entrusted the approval of the marriage of officers with the permission of the colonel commander as well as the regimental commander and the assembly of officers. It also made the deposit of a marriage deposit mandatory. This deposit initially provided an income for the retired officers and also provided a further support for the widowed wife. In general, the higher the rank of the officer intending to marry, the smaller the amount he had to deposit. Of course there were always exceptions, because with the permission of the ruler it was possible to marry even without a deposit. Although at that time the widow was not paid any kind of pension. However, the amount of the deposit continued to rise. For example, a lieutenant had to deposit 60,000 crowns, thirty times his annual income. Until 1913, only the Minister of Defense could authorize the marriage of those facing actual military service. For marriage before the conscription age was generally forbidden. In practice, this prevented marriage before the age of 24 . This is because the majority of young people have already completed their compulsory military service by the age of 24 and have moved from the actual service to the reserve. Thus, family life could no longer make it more difficult to perform active service. The ban was finally lifted by a circular decree signed on January 20, 1913, by the Minister of Defense Hazai Samu." (DEÁK 1990)

The war significantly rearranged the time course of marriages, which was customary in peacetime and was repeated almost year after year. The distribution of the covenants between the months since August 1914 has been less associated with the feasts and traditions of the peaceful years. Prior to World War I, the fewest covenants were made in July, among others, due to agricultural work, and the peak time was in November. While the carnival period was most conducive to those preparing to get married among the church holidays, it was less common in Advent and December for couples to appear in front of the registrar. Although before August 1914 Hungary was still one of the countries with the highest number of marriages per thousand inhabitants, it lost its leading position significantly during the war. (KSH 1924)

In Hungary, in 1913, there were still 9.2 covenants per thousand inhabitants, thus placing it at the forefront among both the later warriors and the later neutrals. In the following years, the number of marriages in historical Hungary dropped significantly. The year 1915 was particularly unfavorable, as the number of marriages per thousand inhabitants was the lowest during the war at that time. After that, until 1918, there was a gradual rise. In the last year of the war, Hungary was leading amongst many of the countries, both neutrals and countries in war. 
TABLE 2

Number of marriages per thousand inhabitants in some European countries*

\begin{tabular}{|c|c|c|c|c|c|c|}
\hline Counrty & 1913 & 1914 & 1915 & 1916 & 1917 & 1918 \\
\hline \multicolumn{7}{|l|}{ War countries } \\
\hline England & 7,8 & 8,0 & 9,8 & 7,5 & 6,9 & 7,7 \\
\hline Scotland & 7,1 & 7,4 & 7,6 & 6,5 & 6,3 & 7,1 \\
\hline Ireland & 5,1 & 5,4 & 5,6 & 5,2 & 4,9 & 5,2 \\
\hline Italy $^{a}$ & 7,5 & 7,0 & 5,1 & 2,9 & 2,7 & 3,0 \\
\hline France $^{\text {b) }}$ & 7,5 & 5,1 & 2,2 & 3,2 & 4,8 & 5,4 \\
\hline Portugal $^{c)}$ & 6,6 & 6,9 & 6,3 & 5,9 & 5,5 & - \\
\hline Finland & 5,9 & 5,7 & 5,4 & 5,8 & 6,0 & 4,5 \\
\hline Romania & 9,2 & 8,5 & 7,2 & - & - & 8,0 \\
\hline Belgium $^{\text {d) }}$ & 8,1 & 5,5 & 3,4 & 4,2 & 4,5 & 6,0 \\
\hline Germany $^{\mathrm{e})}$ & 7,7 & 6,8 & 4,1 & 4,1 & 4,7 & 5,4 \\
\hline Austria $^{\text {f) }}$ & 6,7 & 7,2 & 4,5 & 4,4 & 4,8 & 6,6 \\
\hline Hungary $^{\mathrm{g})}$ & 9,2 & 7,2 & 3,2 & 3,4 & 4,1 & 6,9 \\
\hline \multicolumn{7}{|l|}{ Neutrals } \\
\hline Sweden & 5,9 & 5,5 & 5,8 & 6,2 & 6,2 & 6,7 \\
\hline Norway & 6,3 & 6,5 & 6,5 & 6,9 & 7,2 & 7,8 \\
\hline Switzerland & 6,9 & 5,7 & 5,1 & 5,8 & 6,0 & 6,7 \\
\hline Denmark & 7,2 & 6,9 & 6,5 & 7,2 & 7,0 & 7,7 \\
\hline Netherlands & 7,8 & 6,8 & 6,7 & 7,2 & 7,4 & 7,3 \\
\hline Spain & 6,8 & 6,5 & 6,2 & 6,6 & 6,8 & 6,7 \\
\hline
\end{tabular}

a) Numbers of northern Italian villages not included:. 234 in 1917 and 268 in 1918. b) Only 77 dep. c) Together with the Azores and Madeira. d) Between 1914-1918, excluding 60 villages in West Flanders. e) 1917 és 1918 excluding Alsace-Lorraine. f) 1914-1918the border laid down in the Treaty of Saint-Germain is Austria. g) Data for 1918 are incomplete as of October.

Source: A Magyar Szent Korona Országainak 1913-1918. évi népmozgalma. 4.

The war did not significantly change the territorial distribution of marriages per thousand inhabitants. As in previous peaceful years, the lowest proportions can still be found on the right and left banks of the Danube, where during our participation in the war there were 3.0 and 3.4 marriages per thousand inhabitants. Most covenants were concluded between the Danube and the Tisza (5.8) and in the city of Rijeka (5.2), where the average of the previous peacetime period was also the highest. (KSH 1924)

In the peaceful years, there were nearly as many marriages per thousand inhabitants in the cities as in the countryside. During the war, the number of covenants made in the countryside fell well way below that of the cities, and it could close up only again in the last year of the war. 


\section{CHARACTERISTICS OF MARRIAGES BY AGE GROUP}

The war across Europe has affected the average age of grooms to marry their chosen ones. Although the proportion of grooms between the ages of 20 and 24 remained the highest after the outbreak of World War I, their number decreased by 25 to 40 percent compared to 1913. Compared to the previous peaceful year, the proportion of 25-29 year olds increased slightly in the first year of the war, decreased in 1915, and then began to increase slowly again. The proportion of those over 30 rose sharply between 1915 and 1916, which, in addition to remarriages, may have been due to the fact that military service affected those under 30 to a greater extent. (KSH 1924)

TABLE 3

Age distribution of grooms

(percentage)

\begin{tabular}{|c|c|c|c|c|c|c|c|}
\hline Year & $\begin{array}{c}\text { Under 20 } \\
\text { years }\end{array}$ & $20-24$ & $25-29$ & $30-39$ & $40-49$ & $50-59$ & $\begin{array}{c}\text { Over 60 } \\
\text { years }\end{array}$ \\
\hline 1913 & 7,1 & 41,0 & 30,8 & 12,7 & 4,4 & 2,6 & 1,4 \\
\hline 1914 & 6,0 & 37,1 & 32,1 & 15,4 & 5,1 & 2,2 & 1,5 \\
\hline 1915 & 5,8 & 26,0 & 25,1 & 22,1 & 12,0 & 6,0 & 3,5 \\
\hline 1916 & 4,8 & 28,5 & 26,0 & 17,4 & 11,5 & 7,4 & 4,4 \\
\hline 1917 & 6,2 & 31,2 & 28,7 & 16,3 & 7,6 & 6,1 & 3,0 \\
\hline 1918 & 5,6 & 33,9 & 32,4 & 15,8 & 5,8 & 4,0 & 2,5 \\
\hline
\end{tabular}

Source: A Magyar Szent Korona Országainak 1913-1918. évi népmozgalma. 5.

The impact of war (through the mechanisms of getting widowed, remarriages, and postponement) is also reflected in the evolution of the age distribution of brides. While the proportion of those under 20 decreased compared to 1913, that of those over 30 increased.

\section{TERMINATED MARRIAGES}

As in peacetime, during the war years, marriages were terminated mostly due to the death of the spouse. Between 1914 and 1918, battlefield deaths, results of unfavorable public health and economic conditions - except in 1916 - increased, and while the number of marriages terminated due to deaths increased, while the number of divorces decreased. Judicial divorce is granted by Act XXXI of 1894. defined by law. according to which a divorce is possible only " . . if the marriage is so broken up that the further cohabitation has become unbearable for one or both parties". The law also mentions the institution of so-called "separation from bed and table," which may be a solution for those who, for religious reasons, cannot choose a judicial divorce. (HeINZ 2000)

While in 1913 there were 649 per thousand new marriages, in 1915, when the number of marriages fell the most, there were more than three times as many marriages terminated by death. (ÍsZÁDECZKY-KARDOSS 1924) 


\section{TABLE 4}

Number of marriages terminated

\begin{tabular}{|l|c|c|c|c|}
\hline \multirow{2}{*}{ Year } & \multicolumn{2}{|c|}{ Marriages terminated by death } & \multicolumn{2}{c|}{ Marriages terminated by divorce } \\
\cline { 2 - 5 } & nubmer & $\begin{array}{c}\text { per thousand new } \\
\text { marriages }\end{array}$ & number & $\begin{array}{c}\text { per thousand new } \\
\text { marriage }\end{array}$ \\
\hline 1913 & 111655 & 649 & 7842 & 46 \\
\hline 1914 & 115295 & 846 & 6906 & 51 \\
\hline 1915 & 122926 & 2017 & 2625 & 43 \\
\hline 1916 & 111323 & 1770 & 2323 & 37 \\
\hline 1917 & 113606 & 1499 & 2739 & 36 \\
\hline $1918^{\text {a) }}$ & 149685 & 1180 & - & - \\
\hline
\end{tabular}

a)The 1918 data is not processed.

Source: ÍsZÁDECZKY-KARDOSS 1924. 7.

The number of marriages abolished by divorce fell sharply during the war years, as in several warring countries. In historical Hungary, in the first year of the war, in 1914, there were 51 divorces per thousand new marriages, but in 1917 there were only 36.

\section{BibliograPhy}

Bodart, Gaston (1916): The Loose of Life in Modern Wars. Austria-Hungary; France. OXFORD: AT THE CLARENDON PRESS, London, Edinburgh, New York, Toronto, Melbourne, Bombay 1916.

CSERnÁK JÓZSEFNÉ (1996): Házasság és válás Magyarországon, 1870-1994. Demográfia 2-3. SZ. $108-135$.

DeÁk, István (1990): Beyond Nationalism: A Social and Political History of the Habsburg Officer Corps, 1848-1918. Oxford University Press; 1ST edition (May 24, 1990)

HeInz, ERvin (2000): Népesedéspolitikai intézkedések 1945 előtt. Demográfia 4. sz. 478-498. ÍszÁDECZKY-KARDoss TiBOR (1924): A világháború hatása Magyarország népesedésére. Köznevelés I. évf. 10. sz. 7.

\section{SOURCES}

1886. XXI. article on the law

XXX12 of 1912 law on the defence forces

II of 1915. Act XX of 1886 on the uprising on the amendment and supplementation of the article of law for the duration of the present war $-\S 1$ 
A Magyar Szent Korona Országainak 1913-1918. évi népmozgalma. Magyar statisztikai közlemények, Új sorozat 70. kötet, Magyar Királyi Központi Statisztikai Hivatal, Budapest, 1924

Az 1920. évi Népszámlálás - hatodik rész: Végeredmények összefoglalása. Magyar statisztikai közlemények, Új sorozat 76. kötet. Budapest, 1929, Magyar Királyi Központi Statisztikai Hivatal.

Demográfiai évkönyv, 2007. Budapest, 2008, Központi Statisztikai Hivatal. 